\title{
ASSESSING THE DISABILITY INCLUSIVENESS OF UNIVERSITY BUILDINGS IN HONG KONG
}

\author{
Wai Kin LAU a, Daniel Chi Wing HO ${ }^{\text {a }}$, Yung YAU ${ }^{\text {b,* }}$ \\ a Department of Real Estate and Construction, The University of Hong Kong, Hong Kong, China \\ ${ }^{b}$ Department of Public Policy, City University of Hong Kong, Tat Chee Avenue, Kowloon, Hong Kong, \\ China
}

Received 10 April 2014; accepted 27 May 2015

\begin{abstract}
Tended to view disability inclusion as merely another mandate, building and construction practitioners have yet to recognize its value in social sustainability. In academia, similarly, it has received less attention than other building performance attributes such as environmental friendliness and indoor air quality. With rights to access now acknowledged as basic human rights, there is demand for a tool to assess building disability inclusiveness, indicating the extent to which building considerations include persons with disabilities (PWDs). This paper proposes a Building Inclusiveness Assessment Score (BIAS) to fill the existing gap. The BIAS framework comprises two hierarchies of inclusion attributes identified from literature, guides, and standards of barrier-free access and universal design. The final product consists of two building disability inclusiveness assessment tools: the Physical Disability Inclusion Sub-score (PDIS) and the Visual Impairment Inclusion Sub-score (VIIS). These are simple, quantitative, objective tools for assessing buildings. We performed a Monte Carlo simulation to validate the assessment protocols. Following the validation, we assessed 48 university buildings at four universities in Hong Kong to illustrate the real-life application of the tools.
\end{abstract}

KEYWORDS: Building performance assessment; Disability inclusion; Facility management; Nonstructural fuzzy decision support system; Universal design

\section{INTRODUCTION}

Not only as one of the essential values that represent civil societies, building an inclusive society has also become a goal with universal appeal. Irrespective of differences in race, gender, class, generation and geography, people should enjoy equal opportunities (Atkinson, Marlier 2010). In architecture and facility management, inclusion has often been taken to mean "disability inclusion," which is synonymous with "accessibility" and "barrierfree design." With the United Nations' advocacy of the rights of persons with disabilities (PWDs), the Standard Rules on Equalization of Opportunities for Persons with Disabilities was introduced in 1994 and the Convention on the Rights of Persons with Disabilities was adopted in 2006 to establish PWDs' rights in society and development. The Convention stipulates that signatory states must

\footnotetext{
* Corresponding author. E-mail: y.yau@cityu.edu.hk
}

identify and eliminate obstacles and barriers to accessibility in buildings and other physical environments (United Nations 2006). Since its introduction, access for PWDs to buildings has increasingly become a legal right in many developed countries. It has also become an area of major concern and tough challenge facing facilities managers. Disability inclusion is also relevant to sustainability. As well as being environmentally sustainable, buildings should also be socially and economically sustainable. For buildings and built environments to be more socially sustainable, there should be equity and accessibility for people with different levels of abilities. Furthermore, non-inclusive buildings are not economically sustainable because they fail to capture the enormous opportunities brought by PWDs who comprise approximately $15 \%$ of the world's population (World Health Organization and the World Bank 2011). 
In spite of efforts to foster disability inclusion, built environments are still far from inclusive. In addition to issues with housing and transport, there have long been complaints that higher education facilities are not disability friendly (Borland, James 1999; Chard, Couch 1998). As education is a means of eradicating the poverty problem which tends to be experienced by PWDs, the noninclusive physical environment of universities is detrimental to the social and economic well-being of PWDs. Among the barriers to a fully inclusive built environment, one is building inclusiveness assessment to establish how disability inclusive a building is. At present, assessment is conducted by means of an access audit or access appraisal (Sawyer, Bright 2007). However, these methods have limitations. First, they involve complicated assessment processes using a long checklist. Second, they include many subjective elements that rely heavily on assessors' experience in making judgments (Wu et al. 2007). Thus, there is therefore a research gap in relation to the design of a practical and more objective mechanism to appraise the disability inclusiveness of buildings.

Against this background, the primary aim of this research is to develop an assessment protocol that makes the benchmarking of the inclusiveness of buildings possible. We conducted a comprehensive review of barrier-free and disability-inclusive design guidelines and manuals to construct a hierarchy of attributes for building assessment. We used snowball sampling and invited 63 respondents-building professionals, persons with physical disabilities and persons with visual impairment - to workshops to weigh the categories, attributes and parameters in the two hierarchies. We then applied the assessment framework constructed, the Building Inclusiveness Assessment Score (BIAS), to evaluate and compare the disability inclusiveness of 48 buildings at four universities in Hong Kong.

This article is organized as follows. First, we review existing approaches to the assessment of building disability inclusiveness. Next, we discuss the BIAS framework and the hierarchies for assessment. This is followed by an explanation of how the attribute weightings are determined. We then report and discuss the findings from the onsite assessment, particularly how individual inclusion categories and attributes performed. Finally, the paper ends with conclusions.

\section{ASSESSING THE DISABILITY INCLUSIVENESS OF BUILDINGS}

To build a disability-inclusive society, one answer is to design built facilities based on universal design principles. The idea is to design products, environments, programs and services to be usable by all people to the greatest extent possible, such that neither adaption nor specialization is necessary, and assistive devices for particular groups of PWDs should be included where necessary (Mace et al. 1991; United Nations 2006). Universal design is characterized by seven principles: (1) equitable design; (2) flexibility in use; (3) simple and intuitive use; (4) perceptible information; (5) tolerance for error; (6) low physical effort; (7) size and space for approach and use (The Center for Universal Design 1997). Advocated following World War II, disability inclusion in relation to buildings is believed to have begun with designing for PWDs. In 1959, the US published the first national standard for accessibility, the American Standard A117.1 American Standard Specifications for Making Buildings and Facilities Accessible to, and Usable by, the Physically Handicapped. This standard was later established as the model for corresponding standards and legislation against the exclusion of PWDs in buildings in the UK (Goldsmith 1997). In response to the standards and legislation, there has been keen interest in assessing whether building accessibility complies with the legal requirements. Furthermore, there is also growing interest in assessing the disability inclusiveness of buildings.

The two approaches to the assessment of whether a building is disability inclusive are building performance measurement and building performance assessment. The former approach simply comprises data collection and analysis of the actual performance values of a building in relation to predefined performance parameters. Building performance assessment goes a step further and involves gauging a building's performance against a single criterion or a set of criteria (Francescato 1991). Building performance assessment has a long history, dating back to the 1940s (Duncan 1971). However, it has tended to be limited in scope, focusing primarily on environmental sustainability (e.g., Junnila et al. 2006; Seo et al. 2004), and less on building intelligence (Alwaer, Clements-Croome 2010; So, Wong 2002), health and hygiene (Ho et al. 2004), and safety (Ho et al. 2012; Yau et al. 
2008). Little attention has yet been paid to disability inclusion in studies of building performance assessment.

As confirmed by a comprehensive review, most literature employs users' experiences or opinions to evaluate disability inclusiveness and the accessibility of buildings (Evcil 2009; Kadir, Jamaludin 2012; Thapar et al. 2004). This measure of the disability-friendliness of the built environment is notoriously subjective and the measurement results vary according to evaluators' past experience and expectations. Thus, this approach does not fulfil the objective of performance assessment. What other studies (e.g., Bendel 2006; Chan et al. 2009b; Hashim et al. 2012; Ormerod 2005; Sawyer, Bright 2007; Wood 1999) have done is undertake accessibility audits for the evaluation of inclusiveness. Such audits tend to be subjective and most building performance assessment reports are too technical or complicated for non-experts. Quantifiable assessment results are preferable as they make direct comparison or benchmarking of disability inclusiveness possible. This in turn allows building owners and facilities managers to prioritize their resources in making sensible adjustments or improvements to existing building facilities (Wu et al. 2007).

Assessment of disability inclusiveness generally involves several criteria. Some kind of multiattribute assessment model is therefore needed (Bendel 2006; Kane et al. 2002). However, previous empirical studies have not taken into account the fact that different attributes may command different levels of significance in the overall inclusiveness of a building. In addition, most existing inclusiveness assessment models (e.g., Iwarsson 1999) only address accessibility issues in the design and construction stages of the whole life cycle of the built environment. Building management and operations are often overlooked. The shortfalls in existing approaches to evaluation and disability inclusiveness assessment models call for an appraisal model which is objective, quantitative and easy to use. This study aims to develop a practical and theoretically sound model. It proposes a multiattribute assessment model to assess the disability inclusiveness of university buildings using quantifiable and objectively measurable building attributes related to both the design and management of buildings.

\section{DEVELOPMENT OF THE BUILDING INCLUSIVENESS ASSESSMENT SCORE (BIAS)}

To develop a quantitative appraisal model for assessing the disability inclusiveness of university buildings, this research began with a comprehensive review of literature, guides and standards relevant to the subject. We studied the design guidelines and standards for Canada, Hong Kong, Singapore, the US and the UK to identify suitable building attributes for inclusion in the model (Building and Construction Authority 2007a, 2007b; Buildings Department 2008; British Standards Institute 2009; International Code Council 2009; National Research Council Canada and Institute for Research in Construction 2010; Peloquin 1994; Sawyer, Bright 2007). Three principles guided the selection of attributes or factors for the assessment model. First, the attributes to be evaluated have to be highly relevant in determining the disability inclusiveness of university buildings. Second, the attributes should be sufficiently flexible to embrace most settings of university facilities around the world. Third, for the sake of practicality and objectivity, the attributes should be easily observable, measurable and verifiable.

In line with these principles, we identified potential building attributes for inclusion in the assessment model. We then group these attributes under different categories and structured them into two hierarchies of inclusiveness performance indicators as shown in Figures 1 and 2. Underneath the attributes were various accompanying, operational parameters, shown in Tables 1 and 2 . One of the hierarchies was tailored to assess the level of inclusion for the physically impaired in the university built environment, whereas the other was for the visually impaired. There are two reasons for using two hierarchies instead of a single one. First, some attributes and parameters apply to the physically impaired but not the visually impaired. For example, the visually impaired rarely drive to work or study notwithstanding advances in technology. Second, people with different types of disability have dissimilar levels of reliance on the same building attribute. For that reason, separate hierarchies can facilitate the determination of attribute weightings with respect to different disability types in a later stage.

The two hierarchies consist of five levels. The top level, which contains the goals of the two 


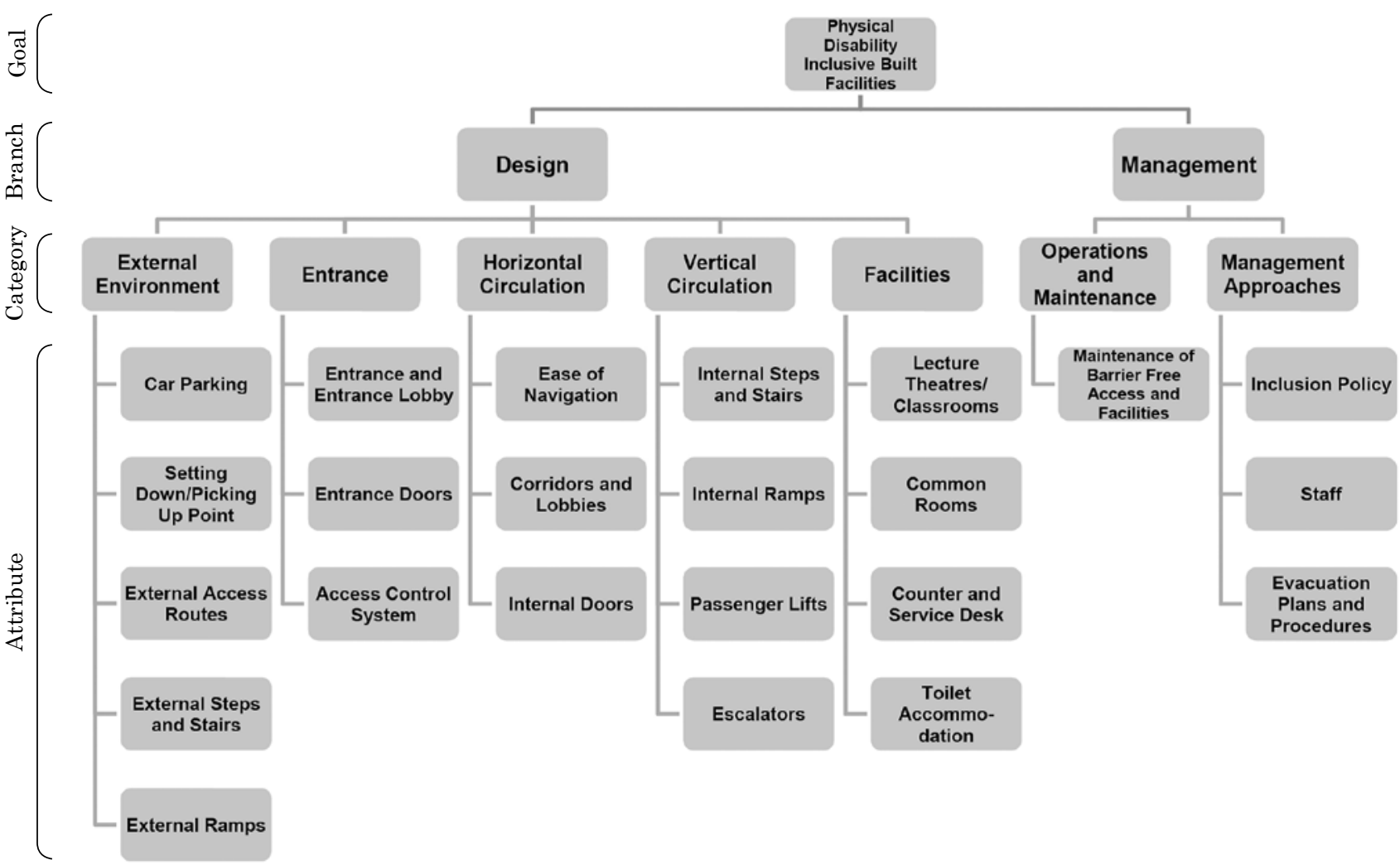

Fig. 1. Hierarchy of assessment attributes in relation to the physical disability inclusiveness of university buildings

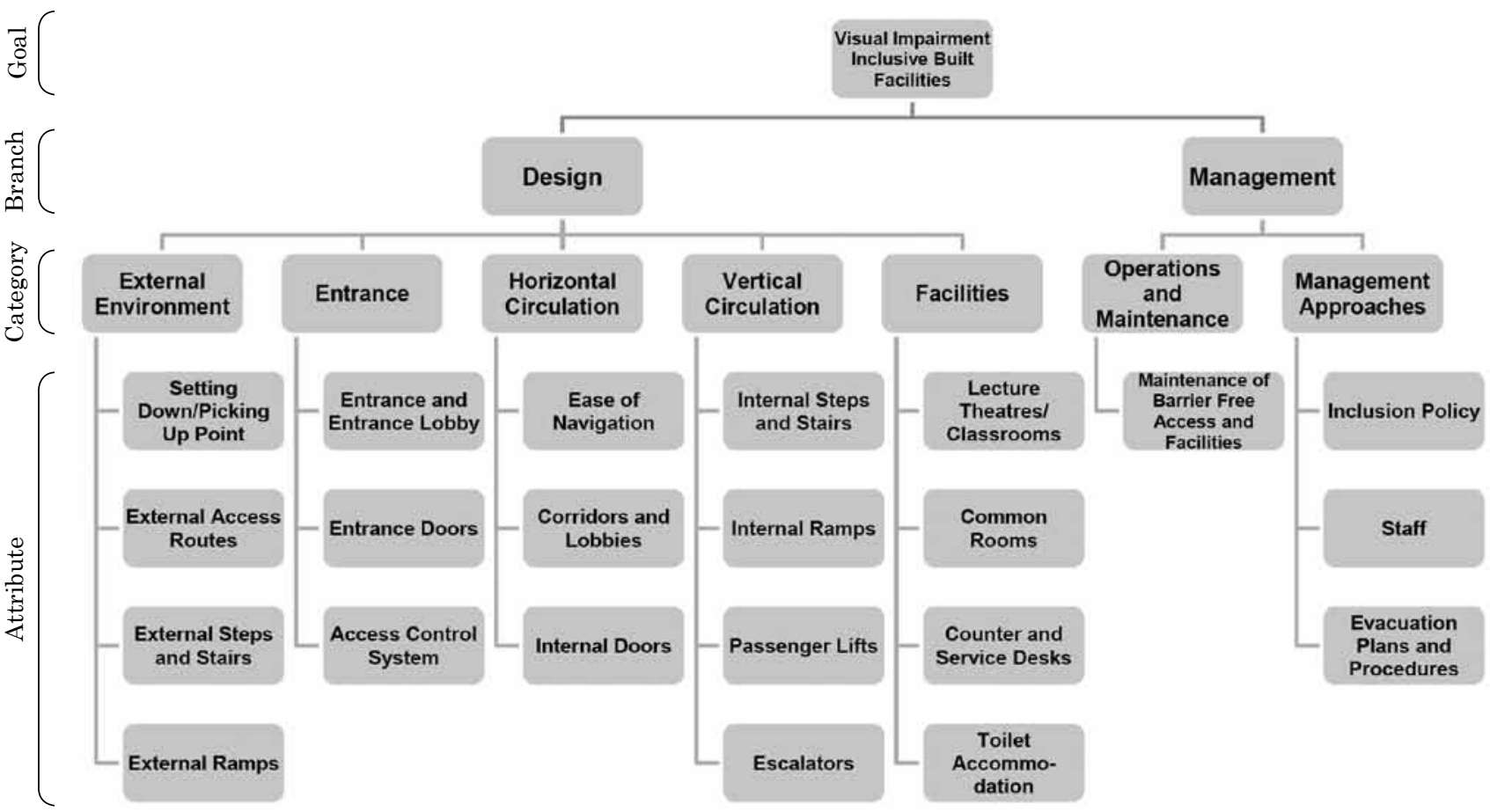

Fig. 2. Hierarchy of assessment attributes in relation to the visual impairment inclusiveness of university buildings 
Table 1. Inclusion categories, attributes and parameters for the PDIS and weightings

\begin{tabular}{|c|c|c|c|}
\hline Branch & Category & Attribute & Parameter \\
\hline \multirow[t]{19}{*}{$\begin{array}{l}\text { Design } \\
(61.74 \%)\end{array}$} & \multirow[t]{5}{*}{$\begin{array}{l}\text { External environ- } \\
\text { ment }(10.42 \%)\end{array}$} & Car parking (1.44\%) & $\begin{array}{l}\text { Provision of accessible parking spaces }(0.74 \%) \\
\text { Design of accessible parking spaces }(0.70 \%)\end{array}$ \\
\hline & & Setting down point $(2.17 \%)$ & Design of setting down point $(2.17 \%)$ \\
\hline & & $\begin{array}{l}\text { External access route } \\
(2.56 \%)\end{array}$ & $\begin{array}{l}\text { Design of external access route }(1.39 \%) \\
\text { Surface of external access route }(1.17 \%)\end{array}$ \\
\hline & & $\begin{array}{l}\text { External steps and stairs } \\
(1.62 \%)\end{array}$ & $\begin{array}{l}\text { Design of external steps and stairs }(0.56 \%) \\
\text { Handrails of external steps and stairs }(0.56 \%) \\
\text { Surface of external steps and stairs }(0.50 \%)\end{array}$ \\
\hline & & External ramps (2.64\%) & $\begin{array}{l}\text { Design of external ramps }(1.04 \%) \\
\text { Handrails of external ramps }(0.73 \%) \\
\text { Surface of external ramps }(0.87 \%)\end{array}$ \\
\hline & \multirow[t]{3}{*}{ Entrance $(12.39 \%)$} & $\begin{array}{l}\text { Entrance and entrance lobby } \\
(4.02 \%)\end{array}$ & $\begin{array}{l}\text { Design of entrance and entrance lobby }(2.11 \%) \\
\text { Surface of entrance and entrance lobby }(1.91 \%)\end{array}$ \\
\hline & & Entrance doors $(4.95 \%)$ & $\begin{array}{l}\text { Design of entrance doors }(1.77 \%) \\
\text { Fittings of entrance doors }(1.32 \%) \\
\text { Operation of entrance doors }(1.85 \%)\end{array}$ \\
\hline & & $\begin{array}{l}\text { Access control system } \\
(3.42 \%)\end{array}$ & Design of access control system (3.42\%) \\
\hline & \multirow{3}{*}{$\begin{array}{l}\text { Horizontal circula- } \\
\text { tion }(10.21 \%)\end{array}$} & Ease of navigation $(3.40 \%)$ & Ease of navigation $(3.40 \%)$ \\
\hline & & $\begin{array}{l}\text { Corridors and lobbies } \\
(3.26 \%)\end{array}$ & $\begin{array}{l}\text { Design of corridors and lobbies }(1.72 \%) \\
\text { Surface of corridors and lobbies }(1.54 \%)\end{array}$ \\
\hline & & Internal doors $(3.55 \%)$ & $\begin{array}{l}\text { Design of internal doors }(1.23 \%) \\
\text { Fittings of internal doors }(1.01 \%) \\
\text { Operation of internal doors }(1.31 \%)\end{array}$ \\
\hline & \multirow[t]{4}{*}{$\begin{array}{l}\text { Vertical circulation } \\
(14.56 \%)\end{array}$} & $\begin{array}{l}\text { Internal steps and stairs } \\
(2.49 \%)\end{array}$ & $\begin{array}{l}\text { Design of internal steps and stairs }(0.87 \%) \\
\text { Handrails of internal steps and stairs }(0.86 \%) \\
\text { Surface of internal steps and stairs }(0.77 \%)\end{array}$ \\
\hline & & Internal ramps $(4.16 \%)$ & $\begin{array}{l}\text { Design of internal ramps }(1.52 \%) \\
\text { Handrails of internal ramps }(1.24 \%) \\
\text { Surface of internal ramps }(1.40 \%)\end{array}$ \\
\hline & & Passenger lifts $(5.30 \%)$ & $\begin{array}{l}\text { Provision of lifts for PWDs }(1.16 \%) \\
\text { Design of lifts for PWDs }(1.15 \%) \\
\text { Lift door operation }(0.99 \%) \\
\text { Control buttons of passenger lifts }(0.98 \%) \\
\text { Emergency equipment }(1.02 \%)\end{array}$ \\
\hline & & Escalators $(2.61 \%)$ & Design of escalators $(2.61 \%)$ \\
\hline & \multirow[t]{4}{*}{ Facilities $(14.19 \%)$} & $\begin{array}{l}\text { Lecture theatres/classrooms } \\
(3.56 \%)\end{array}$ & $\begin{array}{l}\text { Design of lecture theatres/classrooms }(2.02 \%) \\
\text { Building services of lecture theatres/classrooms } \\
(1.54 \%)\end{array}$ \\
\hline & & Common rooms (3.28\%) & $\begin{array}{l}\text { Design of common rooms (1.55\%) } \\
\text { Building services of common rooms (1.73\%) }\end{array}$ \\
\hline & & $\begin{array}{l}\text { Counters and service desks } \\
(2.74 \%)\end{array}$ & $\begin{array}{l}\text { Design of counters and service desks }(1.65 \%) \\
\text { Building services of counters and service desks } \\
(1.09 \%)\end{array}$ \\
\hline & & $\begin{array}{l}\text { Toilet accommodation } \\
(4.58 \%)\end{array}$ & $\begin{array}{l}\text { Provision of accessible toilet }(1.59 \%) \\
\text { Design of accessible toilet }(1.81 \%) \\
\text { Emergency call bell }(1.19 \%)\end{array}$ \\
\hline \multirow[t]{4}{*}{$\begin{array}{l}\text { Management } \\
(38.26 \%)\end{array}$} & $\begin{array}{l}\text { Operations and } \\
\text { maintenance } \\
(18.04 \%)\end{array}$ & $\begin{array}{l}\text { Maintenance of disability } \\
\text { inclusive access and facilities } \\
(18.04 \%)\end{array}$ & $\begin{array}{l}\text { Maintenance of disability inclusive access and facili- } \\
\text { ties }(18.04 \%)\end{array}$ \\
\hline & \multirow{3}{*}{$\begin{array}{l}\text { Management ap- } \\
\text { proaches }(20.22 \%)\end{array}$} & Inclusion policy $(6.47 \%)$ & Inclusion policy $(6.47 \%)$ \\
\hline & & Staff $(6.71 \%)$ & Staff $(6.71 \%)$ \\
\hline & & $\begin{array}{l}\text { Evacuation plans and proce- } \\
\text { dures }(7.04 \%)\end{array}$ & Evacuation plans and procedures (7.04\%) \\
\hline
\end{tabular}


Table 2. Inclusion categories, attributes and parameters for the VIIS and weightings

\begin{tabular}{|c|c|c|c|}
\hline Branch & Category & Attribute & Parameter \\
\hline \multirow{18}{*}{$\begin{array}{l}\text { Design } \\
(56.06 \%)\end{array}$} & \multirow{4}{*}{$\begin{array}{l}\text { External environ- } \\
\text { ment }(12.01 \%)\end{array}$} & Setting down point (3.00\%) & Design of setting down point (3.00\%) \\
\hline & & $\begin{array}{l}\text { External access route } \\
(3.46 \%)\end{array}$ & $\begin{array}{l}\text { Design of external access route }(1.85 \%) \\
\text { Surface of external access route }(1.61 \%)\end{array}$ \\
\hline & & $\begin{array}{l}\text { External steps and stairs } \\
(3.03 \%)\end{array}$ & $\begin{array}{l}\text { Design of external steps and stairs }(1.07 \%) \\
\text { Handrails of external steps and stairs }(0.88 \%) \\
\text { Surface of external steps and stairs }(1.09 \%)\end{array}$ \\
\hline & & External ramps $(2.52 \%)$ & $\begin{array}{l}\text { Handrails of external ramps }(1.16 \%) \\
\text { Surface of external ramps }(1.36 \%)\end{array}$ \\
\hline & \multirow[t]{3}{*}{ Entrance (11.11\%) } & $\begin{array}{l}\text { Entrance and entrance lobby } \\
(3.83 \%)\end{array}$ & $\begin{array}{l}\text { Design of entrance and entrance lobby }(1.37 \%) \\
\text { Surface of entrance and entrance lobby }(1.19 \%) \\
\text { Illumination of entrance and entrance lobby }(1.28 \%)\end{array}$ \\
\hline & & Entrance doors (3.75\%) & $\begin{array}{l}\text { Design of entrance doors }(1.97 \%) \\
\text { Fittings of entrance doors }(1.78 \%)\end{array}$ \\
\hline & & $\begin{array}{l}\text { Access control system } \\
(3.52 \%)\end{array}$ & Design of access control system (3.52\%) \\
\hline & \multirow{3}{*}{$\begin{array}{l}\text { Horizontal circula- } \\
\text { tion }(9.99 \%)\end{array}$} & Ease of navigation (3.94\%) & Ease of navigation (3.94\%) \\
\hline & & $\begin{array}{l}\text { Corridors and lobbies } \\
(2.97 \%)\end{array}$ & $\begin{array}{l}\text { Design of corridors and lobbies }(1.12 \%) \\
\text { Surface of corridors and lobbies }(0.91 \%) \\
\text { Illumination of corridors and lobbies }(0.94 \%)\end{array}$ \\
\hline & & Internal doors $(3.08 \%)$ & $\begin{array}{l}\text { Design of internal doors }(1.63 \%) \\
\text { Fittings of internal doors }(1.45 \%)\end{array}$ \\
\hline & \multirow[t]{4}{*}{$\begin{array}{l}\text { Vertical circulation } \\
(11.28 \%)\end{array}$} & $\begin{array}{l}\text { Internal steps and stairs } \\
(2.75 \%)\end{array}$ & $\begin{array}{l}\text { Design of internal steps and stairs }(0.75 \%) \\
\text { Handrails of internal steps and stairs }(0.68 \%) \\
\text { Surface of internal steps and stairs }(0.70 \%) \\
\text { Illumination of internal steps and stairs }(0.62 \%)\end{array}$ \\
\hline & & Internal ramps (2.14\%) & $\begin{array}{l}\text { Handrails of internal ramps }(0.71 \%) \\
\text { Surface of internal ramps }(0.78 \%) \\
\text { Illumination of internal ramps }(0.66 \%)\end{array}$ \\
\hline & & Passenger lifts (3.73\%) & $\begin{array}{l}\text { Design of lifts for PWDs }(0.74 \%) \\
\text { Control buttons of passenger lifts }(0.84 \%) \\
\text { Indication and notifications }(0.89 \%) \\
\text { Emergency equipment }(0.68 \%) \\
\text { Illumination of passenger lifts }(0.59 \%)\end{array}$ \\
\hline & & Escalators $(2.65 \%)$ & Design of escalators $(2.65 \%)$ \\
\hline & \multirow[t]{4}{*}{ Facilities (11.67\%) } & $\begin{array}{l}\text { Lecture theatres/classrooms } \\
(3.23 \%)\end{array}$ & $\begin{array}{l}\text { Design of lecture theatres/classrooms }(1.84 \%) \\
\text { Building services of lecture theatres/classrooms } \\
(1.39 \%)\end{array}$ \\
\hline & & Common rooms $(2.36 \%)$ & $\begin{array}{l}\text { Design of common rooms }(1.25 \%) \\
\text { Building services of common rooms }(1.11 \%)\end{array}$ \\
\hline & & $\begin{array}{l}\text { Counters and service desks } \\
(2.60 \%)\end{array}$ & $\begin{array}{l}\text { Design of counters and service desks }(1.47 \%) \\
\text { Building services of counters and service desks } \\
(1.13 \%)\end{array}$ \\
\hline & & $\begin{array}{l}\text { Toilet accommodation } \\
(3.49 \%)\end{array}$ & $\begin{array}{l}\text { Provision of accessible toilet }(1.20 \%) \\
\text { Design of toilet }(1.27 \%) \\
\text { Emergency call bell in accessible toilet }(1.03 \%)\end{array}$ \\
\hline \multirow[t]{4}{*}{$\begin{array}{l}\text { Management } \\
(43.94 \%)\end{array}$} & $\begin{array}{l}\text { Operations and } \\
\text { maintenance } \\
(19.76 \%)\end{array}$ & $\begin{array}{l}\text { Maintenance of disability } \\
\text { inclusive access and facilities } \\
(19.76 \%)\end{array}$ & $\begin{array}{l}\text { Maintenance of Disability inclusive access and fa- } \\
\text { cilities }(19.76 \%)\end{array}$ \\
\hline & \multirow{3}{*}{$\begin{array}{l}\text { Management ap- } \\
\text { proaches }(24.18 \%)\end{array}$} & Inclusion policy $(8.70 \%)$ & Inclusion policy $(8.70 \%)$ \\
\hline & & Staff $(8.22 \%)$ & Staff $(8.22 \%)$ \\
\hline & & $\begin{array}{l}\text { Evacuation plans and proce- } \\
\text { dures }(7.26 \%)\end{array}$ & Evacuation plans and procedures $(7.26 \%)$ \\
\hline
\end{tabular}


hierarchies, indicates the overall inclusiveness of a university building. At the subordinate level, the general goals are decomposed into two branches, Design and Management. The Design branch represents the hardware supporting disability inclusion and embraces building attributes related to the physical features of buildings. These attributes are usually those outlined in the inclusive design guidelines and standards. The Management branch covers software that makes a building inclusive and covers actions or initiatives taken to plan, monitor and maintain an inclusive environment. This division is sensible because it does not merely consider the hardware of buildings to address inclusion issues. How the buildings are managed and maintained also matters in the assessment of disability inclusiveness.

The third level of the hierarchies comprises seven categories, with five under Design and two under Management. The five design-related categories are External Environment, Entrance, Horizontal Circulation, Vertical Circulation and Facilities, and the two management-related categories are Operation and Maintenance and Management Approaches. The fourth level comprises the building attributes, which are grouped under their respective categories. In all, there are 23 and 22 attributes in the hierarchies for inclusion of the physically impaired and the visually impaired respectively. To facilitate objective assessment of how a building performs with regard to a particular attribute, the attribute may be broken down into different operational parameters, forming the fifth level. A rating scale is applied to each of these parameters for consistent evaluation. As an example, Table 3 illustrates the assessment of the attribute External Access Routes in the two hierarchies using predetermined scoring tables.

Table 3. Examples of PDIS and VIIS rating scales

\begin{tabular}{lll}
\hline Attribute & Parameter & Description
\end{tabular}

PDIS (for persons with physical impairment)

External access routes
Design of external access routes (PD3.1)

External access routes have a clear width

- of $1,500 \mathrm{~mm}$ or more

- of $1,050 \mathrm{~mm}$ to $1,500 \mathrm{~mm}$

External access routes are free of barriers including steps, curbs other than dropped curbs, steep ramps, doors or doorways impeding passage of wheelchairs, and inadequate maneuvering space for wheelchairs. Indication signage for accessible routes or entrances is provided.

PD3.1 $=$

Surface of external access route is

Surface of external access routes (PD3.2)

- firm

- even

- slip-resistant

$\begin{array}{ll}\text { PD3.1 }= & / 4 \\ & 1 \\ & 1 \\ \text { PD3.2 }= & 1 \\ & \end{array}$

VIIS (for persons with visual impairment)

External access routes
Design of external access routes (VD2.1)
External access routes are free of barriers including protrusion hazards, channel covers that are not flush or have holes in them with a dimension larger than 20 $\mathrm{mm}$, and gratings with a width more than $13 \mathrm{~mm}$ or parallel to the pedestrian travel path.

Warning guardrails or other barriers are provided where headroom is less than $2,000 \mathrm{~mm}$.

A tactile guide path is provided from the lot boundary to the entrance of a building and/or where floor space is larger than $200 \mathrm{~m}^{2}$.

Patterns in floor finishes are consistent.

$$
\text { VD2.1 = }
$$

Surface of external access routes (VD2.2)
Floor surfaces are not reflective.

Floor surfaces are luminously contrasted with walls and ceiling.

Surfaces of tactile guide paths are luminously contrasted with adjoining finishes. 
The scoring tables set out the rules governing the rating of quantitative attributes in the assessment scheme. We designed these with reference to legal requirements, relevant design guides and standards, best practices in the building industry, and recommendations made by disability concern groups. A score is assigned to each parameter depending on how many criteria the building under assessment fulfils. In the example illustrated in Table 3 , the score ranges from 0 to 4 for parameter PD3.1. A low score indicates disability exclusion, whereas a higher score means a higher level of disability inclusiveness.

For ease of application, the complex assessment results with respect to the building attributes should be aggregated and transformed into some simple indices. In light of this, we developed a Building Inclusiveness Assessment Score (BIAS). The BIAS was taken as the arithmetic mean of two indices, namely the Physical Disability Inclusion Sub-score (PDIS) and the Visual Impairment Inclusion Sub-core (VIIS). The PDIS and the VIIS are weighted arithmetic means of the ratings of the attributes (and the parameters) that affect the disability inclusiveness of university buildings for the physically impaired and the visually impaired respectively. Mathematically:

$$
\begin{aligned}
& \operatorname{PDIS}_{k}=\sum_{i=1}^{23} w_{k i} F_{k i} \text { and } \\
& V I I S_{k}=\sum_{j=1}^{22} v_{k j} G_{k j},
\end{aligned}
$$

where: $P D I S_{a}$ and VIIS $_{a}$ are the PDIS and the VIIS respectively of building $k ; w_{k i}(i=1,2, \ldots$, 23) denotes the non-negative weighting of the $i$ th inclusion attribute of building $k$ related to physical disability; $v_{k j}(j=1,2, \ldots, 22)$ denotes the nonnegative weighting of the $j$ th inclusion attribute of building $k$ related to visual impairment; $F_{k i}(i=$ $1,2, \ldots, 23)$ and $G_{k j}(j=1,2, \ldots, 22)$ denote the standardized ratings of the $i$ th and $j$ th inclusion attributes respectively of building $k$. All $w_{k i}$ sum to unity and the same applies to $v_{k j}$. The scale for each $F_{k i}$ and $G_{k j}$ is standardized by taking the ratio of the total score attained for the particular attribute to the maximum score attainable for that attribute and thus it ranges from $0 \%$ to $100 \%$. As can be seen from the above formulae, $P D I S_{k}$ and $V I I S_{k}$ are positively associated with all $F_{k i}$ and $G_{k j}$ provided that $w_{k i}$ and $v_{k j}$ are all positive. To put it differently, the higher an attribute rating $F_{k m}$ (or $G_{k n}$ ), the higher the resulting $P D I S_{k}$ (or VIIS $S_{k}$ ) will be, keeping other ratings constant.

\section{DETERMINATION OF ATTRIBUTE WEIGHTINGS}

There are different approaches to determining the weightings for the building attributes $w_{k i}$ and $v_{k j}$. The direct assignment of weight to each attribute is perhaps the simplest and most easily understandable method. Nonetheless, it is often criticized for the inconsistent results generated, especially when many attributes are involved in each weight determination exercise (Polatidis et al. 2009). Given that there are over 20 attributes and some 50 parameters in each of the hierarchies, as shown in Figures 1 and 2 and Tables 1 and 2, it could be difficult - if not impossible - for decision makers to give a set of consistent weightings to individual attributes and parameters using direct weighting. In contrast, the multi-attribute utility model (MAUM) can generate a highly consistent set of attribute weightings but its operation, even in its simplest version, is notoriously complicated, extremely time-consuming and costly (Yau 2012). In this study, we use the non-structural fuzzy decision support system (NSFDSS), striking a balance between practicality and credibility in the weighting process.

As a multi-criteria decision-making technique, the NSFDSS is much easier to run than the MAUM, but can still generate consistent weighting results. This technique breaks down a decision problem into a series of pair-wise comparisons among decision elements, thus reducing the difficulty of making a judgment (Tam et al. 2002). In addition, logical consistency checks are allowed to enhance the accuracy of problem solving. The analytic hierarchy process (AHP) also has these two features, but it is inferior to the NSFDSS because the latter is simpler in operation and yet can generate more reliable results (Tam et al. 2002). More importantly, the fuzzy sets adopted in the NSFDSS facilitate comparisons and judgments even when vague words and expressions (e.g., "the same", "marginally different" and "significantly different") are used (Chan et al. 2009a; Tam et al. 2006). Due to its many advantages, the NSFDSS has been adopted for weight determination in a wide range of areas, such as site layout planning, renewal project evaluation and residents' decision-making for participation in housing maintenance (Tam et al. 2002; Yau, Chan 2008; Yau 2012).

Figure 3 illustrates the workflow of the NSFDSS and the computational details of the technique can be found in Tam et al. (2002) and Yau 


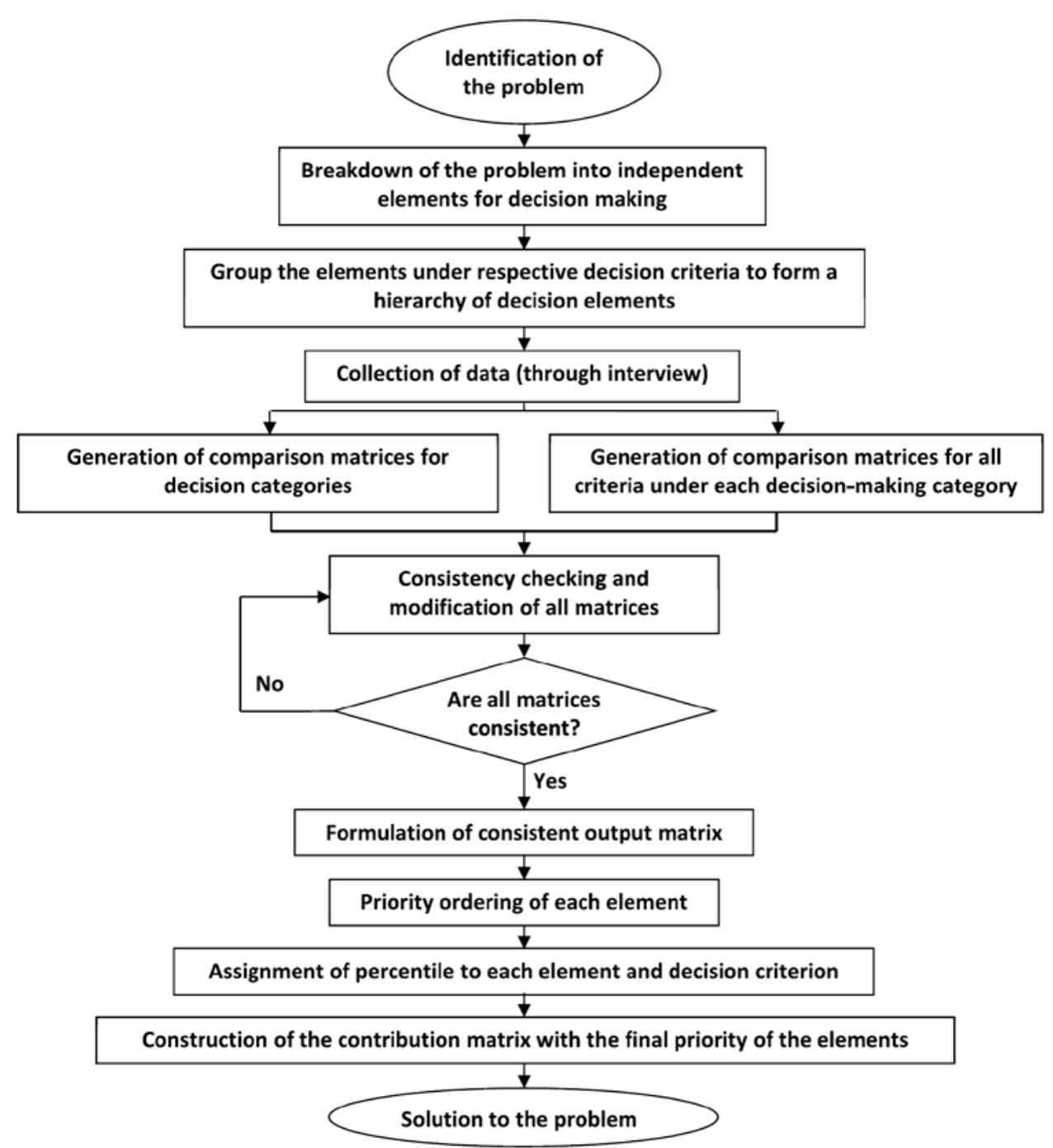

Fig. 3. Work flow of the non-structural fuzzy decision support system (NSFDSS) (adapted from Yau 2012)

(2012). We held workshops to weight the inclusion categories, attributes and parameters in Hong Kong between October 2011 and January 2012, and between March and July 2012. The workshops involved 20 local building professionals (including architects and building surveyors), 22 persons with physical disabilities and 21 persons with visual impairment. The results of the weighting exercises are summarized in Tables 1 and 2 . Management-related attributes in general have heavier weights compared with the design-related counterparts. That said, however, the overall weight put on the Design branch is greater than that on the Management branch for both the PDIS and the VIIS hierarchies. It is evident from this result that hardware still plays a more important role than software in determining the disability inclusiveness of a building.

\section{SENSITIVITY ANALYSIS}

We performed a sensitivity analysis using a Monte Carlo simulation to ensure the reliability of the assessment results using the PDIS and the VIIS frameworks. A score was randomly generated from a prescribed range for each attribute, and the resulting PDIS and VIIS were examined. Three scenarios, namely good, average and poor inclusiveness performance, were set for the test. The scores were uniformly distributed within the ranges $(60 \%$ to $100 \%),(40 \%$ to $60 \%)$ and ( $0 \%$ to $40 \%)$ respectively. A case of scores in the range ( $0 \%$ to $100 \%)$ was also tested. 1,000 iterations were tried for each of these four scenarios. For the PDIS and the VIIS to have a high level of predictive accuracy, the simulated scores should be normally distributed around $50 \%, 80 \%, 50 \%$ and $20 \%$ for the overall $(0 \%$ to $100 \%)$, good (60\% to $100 \%)$, average ( $40 \%$ to $60 \%)$ and poor ( $0 \%$ to $40 \%)$ scenarios respectively. Other than observing standard deviation, skewness and 
Table 4. Summary of simulated PDIS and VIIS after 1,000 iterations for each scenario

\begin{tabular}{|c|c|c|c|c|c|}
\hline Scenario & & Good (60-100\%) & Average (40-60\%) & Poor (0-40\%) & Overall (0-100\%) \\
\hline \multirow[t]{7}{*}{ PDIS } & Maximum & $87.0 \%$ & $54.7 \%$ & $27.0 \%$ & $68.8 \%$ \\
\hline & Mean & $80.0 \%$ & $50.0 \%$ & $20.2 \%$ & $49.7 \%$ \\
\hline & Minimum & $72.4 \%$ & $45.8 \%$ & $11.6 \%$ & $31.5 \%$ \\
\hline & $\sigma$ & $2.7 \%$ & $1.4 \%$ & $2.7 \%$ & $6.8 \%$ \\
\hline & Skewness & -0.02 & 0.004 & -0.039 & 0.093 \\
\hline & Kurtosis & -0.602 & -0.315 & -0.424 & -0.412 \\
\hline & $\begin{array}{l}\text { Kolmogorov- } \\
\text { Smirnov test, } \\
\text { One sample }\end{array}$ & $\begin{array}{l}\text { Data are normally } \\
\text { distributed }\end{array}$ & $\begin{array}{l}\text { Data are normally } \\
\text { distributed }\end{array}$ & $\begin{array}{l}\text { Data are normally } \\
\text { distributed }\end{array}$ & $\begin{array}{l}\text { Data are normally } \\
\text { distributed }\end{array}$ \\
\hline \multirow[t]{7}{*}{ VIIS } & Maximum & $87.4 \%$ & $54.0 \%$ & $29.3 \%$ & $71.0 \%$ \\
\hline & Mean & $80.1 \%$ & $50.0 \%$ & $20.0 \%$ & $49.6 \%$ \\
\hline & Minimum & $70.8 \%$ & $45.0 \%$ & $11.6 \%$ & $28.8 \%$ \\
\hline & $\sigma$ & $3.0 \%$ & $1.5 \%$ & $3.0 \%$ & $7.1 \%$ \\
\hline & Skewness & -0.132 & -0.055 & 0.057 & 0.063 \\
\hline & Kurtosis & -0.468 & -0.515 & -0.277 & -0.243 \\
\hline & $\begin{array}{l}\text { Kolmogorov- } \\
\text { Smirnov test, } \\
\text { One sample }\end{array}$ & $\begin{array}{l}\text { Data are normally } \\
\text { distributed }\end{array}$ & $\begin{array}{l}\text { Data are normally } \\
\text { distributed }\end{array}$ & $\begin{array}{l}\text { Data are normally } \\
\text { distributed }\end{array}$ & $\begin{array}{l}\text { Data are normally } \\
\text { distributed }\end{array}$ \\
\hline
\end{tabular}

kurtosis of the simulated scores, a more advanced method, the Kolmogorov-Smirmov test, was modified to serve as a goodness of fit test for testing normal distribution. The idea is to compare the standardized samples with a standard normal distribution. For doing so the mean and variance of the reference distribution are set to be equal to the sample estimates, and this way of defining the specific reference distribution changes the null distribution of the test statistic. By using add-on in Microsoft Excel, one sample Kolmogorov-Smirnov test was performed. The test results, together with the summary statistics of the 4,000 simulated assessment results which signify the robustness of the two indicators, are shown in Table 4.

\section{ASSESSING THE DISABILITY INCLUSIVENESS OF UNIVERSITY BUILDINGS USING THE BIAS}

Assessing the disability inclusiveness of a university building using the BIAS is a four-stage process. What comes first is a desk study in which the site layout and building plans are studied. An on-site evaluation is then conducted during which visual inspection and measurements against assessment proformas are performed. This is then followed by documentary inspection and structured interviews. Documents relevant to disability inclusion policy in a university, including maintenance plans and working manuals for disability, are examined. Fi- nally, the information and data collected in the preceding stages are verified and consolidated.

We followed these procedures to assess 48 university buildings at four universities in Hong Kong during the period between March and September 2013. Among the buildings surveyed, 25 buildings (52.1\%) were at the University of Hong Kong (HKU), eight (16.7\%) at the City University of Hong Kong (CityU), seven (14.6\%) at the Hong Kong Baptist University (HKBU), and eight (16.7\%) at the Hong Kong Polytechnic University (HKPU). The PDIS and the VIIS assessment results for the buildings are summarized in Tables 5 and 6 respectively.

Table 5. Summary statistics of the PDIS assessment results

\begin{tabular}{llllll}
\hline & HKU & PolyU & CityU & BU & Overall \\
\hline Maximum & $76.3 \%$ & $68.2 \%$ & $69.3 \%$ & $69.6 \%$ & $76.3 \%$ \\
Mean & $69.0 \%$ & $65.7 \%$ & $62.4 \%$ & $64.3 \%$ & $66.7 \%$ \\
Median & $71.4 \%$ & $66.6 \%$ & $61.2 \%$ & $64.9 \%$ & $68.0 \%$ \\
Minimum & $52.3 \%$ & $62.1 \%$ & $55.8 \%$ & $57.0 \%$ & $52.3 \%$ \\
o & $6.6 \%$ & $2.1 \%$ & $5.2 \%$ & $5.0 \%$ & $6.1 \%$ \\
\hline
\end{tabular}

Table 6. Summary statistics of the VIIS assessment results

\begin{tabular}{lcclll}
\hline & HKU & PolyU & CityU & BU & Overall \\
\hline Maximum & $77.2 \%$ & $66.8 \%$ & $67.9 \%$ & $72.1 \%$ & $77.2 \%$ \\
Mean & $69.2 \%$ & $64.0 \%$ & $63.4 \%$ & $65.1 \%$ & $66.8 \%$ \\
Median & $70.2 \%$ & $64.9 \%$ & $62.9 \%$ & $64.8 \%$ & $66.5 \%$ \\
Minimum & $58.6 \%$ & $57.1 \%$ & $60.1 \%$ & $57.1 \%$ & $57.1 \%$ \\
$\sigma$ & $5.1 \%$ & $3.1 \%$ & $2.5 \%$ & $5.0 \%$ & $5.1 \%$ \\
\hline
\end{tabular}


Because this research does not aim to compare universities in terms of which is the most disability inclusive, we do not discuss how individual universities scored in the PDIS and the VIIS in depth. However, the fact that HKU obtained the highest scores in the PDIS and the VIIS does not indicate that the buildings in this case are more disability inclusive in their design; rather, greater disability inclusive management is the reason for the higher scores. We also note that the physical disability inclusion performance and the visual impairment inclusion performance of the buildings are correlated, that is, the higher the PDIS the higher the VIIS, and vice versa.

Despite this finding, the PDIS and the VIIS merely indicate the overall disability inclusion performance; it is necessary to look further down at the category level to gain a better understanding of the performance of Design and Management in the two scores. In radar diagrams, the percentage scored in different categories in the PDIS and the VIIS are presented in Figures 4 and 5, respectively.

For categories in the PDIS, Operations and Maintenance is the best performing category, indicating that access to the buildings and facilities are well maintained with almost no defects. Attributes under Vertical Circulation show average performance, representing few barriers to access: the Passenger Lifts are sufficiently spacious and can accommodate wheelchair users and are suitable for those with ambulant disabilities to use and operate; the Entrance and Entrance Lobby under Entrance is adequately spaced and appropriately surfaced. $F a$ cilities and Management Approaches fall within the band of poor performance for several reasons: (1) Lecture Theatres or Classrooms are frequently not equipped with wheelchair space and have passages that are too narrow for a wheelchair to navigate; (2)

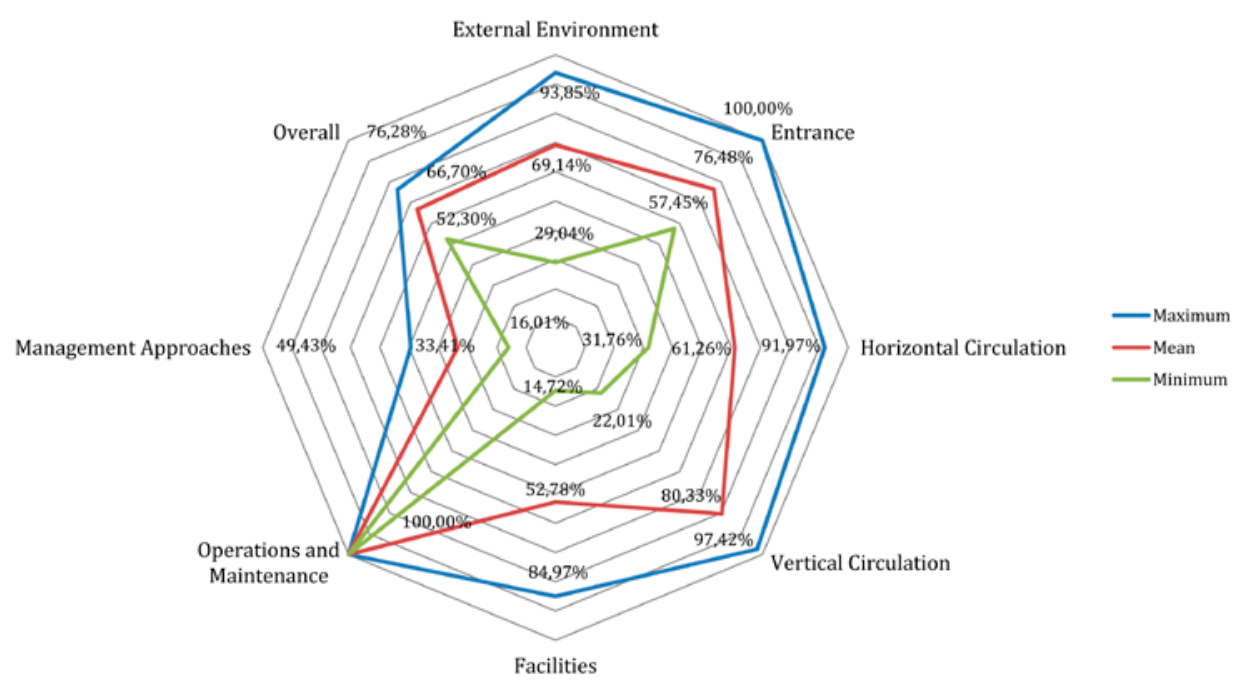

Fig. 4. Radar diagram showing the percentage of PDIS categories scored in the sampled buildings

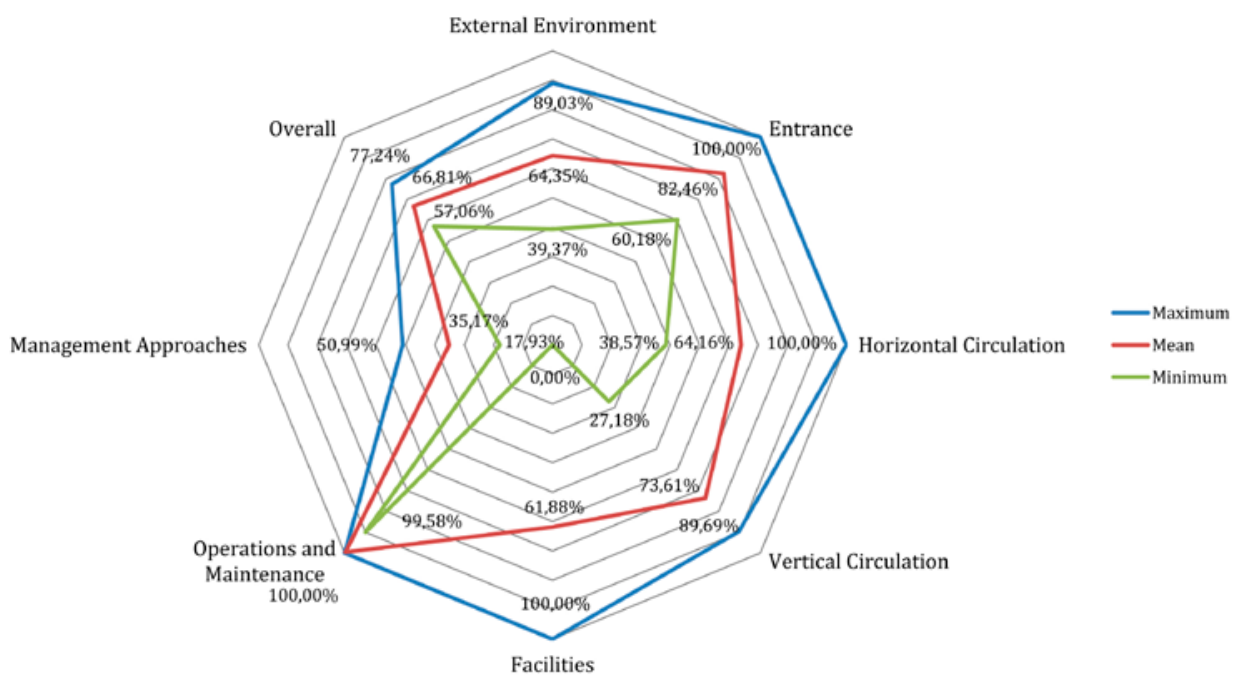

Fig. 5. Radar diagram showing the percentage of VIIS categories scored in the sampled buildings 
the Inclusion Policy is not properly adopted and implemented in the universities studied; (3) Staff who should extend assistance to persons with physical disabilities are not around or lack training in communication with persons with physical disabilities; (4) Evacuation Plans and Procedures are not implemented to help evacuate persons with physical disabilities in the case of emergency. Figure 6 shows how a PDIS item is assessed on site.

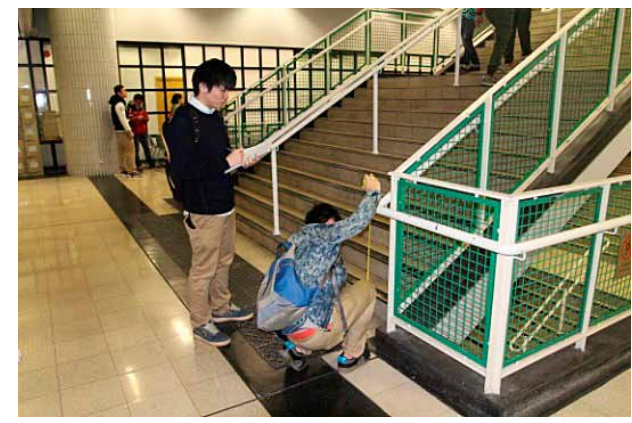

Fig. 6. On-site evaluation of physical disability inclusiveness by measuring height of top of handrails

When it comes to categories in the VIIS, Operations and Maintenance is again the best performing category but there are some defects, such as missing braille and tactile information on handrails. Within Vertical Circulation in the band of average performance, two points warrant note: (1) there is a lack of sufficient contrast in nosings and handrails, and a lack of braille and tactile information on handrails; (2) some essential indications and notifications in Passenger Lifts are missing without which those with visual impairment may become trapped inside lifts. For Facilities, the absence of visual impairment-friendly features, such as contrasting controls and sockets in Lecture Theatres or Classrooms and contrasting sanitary fitments in Toilet Accommodation, are among the reasons for the poor performance in this category. Again Management Approaches is the worst performing category, the reasons for which are similar to those stated in relation to the PDIS. Figure 7 shows some findings from the VIIS assessment.

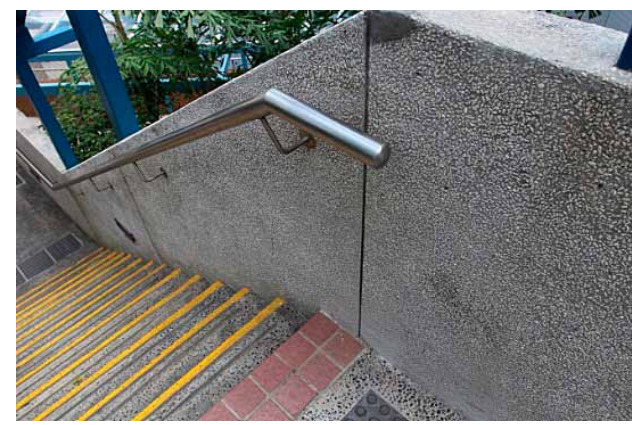

Fig. 7. A lack of braille and tactile information on handrails

\section{DISCUSSION}

This research addresses development of the BIAS framework that aims to fills the current gap in assessment provision. When we constructed the hierarchies, we investigated the factors and elements that make up a physical disability and visual impairment inclusive university building. For (university) buildings to be disability inclusive, both design and management are indispensable. However, to date, there is a lack of research on property management for disability inclusion.

This research not only contributes to knowledge building, but also has practical implications. In particular, the PDIS and the VIIS can be of practical use in three ways. First, although not developed as a design guide for disability inclusive buildings, architects, designers and other interested parties may refer to the PDIS and the VIIS and their rating scales when planning and designing works. Second, the weights of the PDIS and the VIIS categories, attributes and parameters define what building professionals and persons with physical disabilities or visual impairment view as important for disability-inclusive buildings. This is essential information for building professionals and those with oversight on inclusion issues; without such information, they cannot prioritize improvements and/or take appropriate measures to augment disability inclusiveness. In particular, to improve inclusiveness, this study shows that more management action is essential, such as training staff to build their disability awareness. Finally, the PDIS and the VIIS are simple quantitative tools, more objective than access audit or access appraisal, which are currently in use. Using the two tools, the physical disability and visual impairment inclusiveness of buildings can be assessed with greater ease than previously, regardless of whether a building is still in the planning and design stage, is already occupied, is going to undergo improvement works, or is simply subject to a periodic review. In management language, the inclusion performance of a building can be benchmarked.

The tools developed have the potential to be of considerable use to facility managers, building professionals, facility owners and building users. However, the PDIS and the VIIS still entail some 200 items in assessment (i.e., 216 items in the PDIS and 155 items in the VIIS) and will have to be reduced and simplified while remaining comprehensive. As it is, this study has established the research design and the strategy for data collection 
to assess building disability inclusiveness. We are thus in pole position to adjust and apply the BIAS framework to study other types of buildings such as health care facilities and office buildings.

\section{CONCLUSIONS}

Underpinning our decision to develop a simple, quantitative and more objective building disability inclusiveness assessment scheme was the principle that persons, whether or not with disabilities, should have equal rights and PWDs' rights to access and use buildings should be fostered and safeguarded. In line with our research aim, we reviewed literature relevant to the assessment of building performance in relation to disability inclusion, particularly guides and standards for barrier-free access, as well as considering universal design principles in constructing the BIAS framework. We originally sought to develop the BIAS to assess and represent the overall disability inclusiveness of buildings in a single score, but this was later found to be unsuitable; presenting the inclusiveness of a particular disability in a score is preferable. The final product is the PDIS and the VIIS. For both practicality and credibility reasons, we employed the NSFDSS rather than the more popular AHP approach to weigh the inclusion attributes in the hierarchies. We tested the reliability of the PDIS and the VIIS assessment results using a Monte Carlo simulation before employing the two in a real-life application. The building surveys uncovered (non-)inclusive areas in design and management. Interestingly, Operations and Maintenance is the best performing category in both the PDIS and the VIIS, whereas Management Approaches is in the poor performance band. Disability inclusion is an issue of relevance in sustainable buildings as it relates to elements of social and economic sustainability. No matter whether a society is young or aged, inclusion is something that should be championed as the philosophy behind disability inclusion in built facilities is "building for all," rather than building for PWDs only. A socially-inclusive environment will in the end benefit everyone.

\section{ACKNOWLEDGEMENT}

The authors gratefully acknowledge the financial support provided by the HKU 81 Inclusion Fund for the research project "Assessment of the Inclusiveness of Built Facilities" that made this research possible.

\section{REFERENCES}

Alwaer, H.; Clements-Croome, D. J. 2010. Key performance indicators (KPIs) and priority setting in using the multi-attribute approach for assessing sustainable intelligent buildings, Building and Environment 45(4): 799-807. http://dx.doi.org/10.1016/j. buildenv.2009.08.019

Atkinson, A. B.; Marlier, E. 2010. Analysis and measuring social inclusion in a global context. New York: United Nations.

Bendel, J. 2006. Decision support system for evaluating accessibility of facilities, The Israeli Journal of Occupational Therapy 15(3): 1-17.

Borland, J.; James, S. 1999. The learning experience of students with disabilities in higher education: a case study of a UK university, Disability \& Society 14(1): 85-101. http://dx.doi.org/10.1080/09687599926398

British Standards Institute. 2009. Design of buildings and their approaches to meet the needs of disabled people (code of practice BS8300). London: British Standards Institute.

Building and Construction Authority. 2007a. Code on accessibility in the built environment. Building and Construction Authority, Singapore.

Building and Construction Authority. 2007b. Universal design guide. Building and Construction Authority, Singapore.

Buildings Department. 2008. Design manual barrier free access 2008. Buildings Department, Hong Kong.

Chan, A. P. C.; Chan, D. W. M.; Yeung, J. F. Y. 2009a. Overview of the application of 'fuzzy techniques' in construction management research, Journal of Construction Engineering and Management 135(11): 1241-1252. http://dx.doi.org/10.1061/(ASCE) CO.1943-7862.0000099

Chan, E. H. W.; Lee, G. K. L.; Chan, A. T. S. 2009 b. Universal design for people with disabilities: a study of access provisions in public housing estates, Property Management 27(2): 138-146. http://dx.doi. org/10.1108/02637470910946435

Chard, G.; Couch, R. 1998. Access to higher education for the disabled student: a building survey at the University of Liverpool, Disability \& Society 13(4): 603-623. http://dx.doi.org/10.1080/09687599826632

Duncan, T. L. C. 1971. Measuring housing quality: a study of methods, occasional paper no. 20. Centre for Urban and Regional Studies, The University of Birmingham, Birmingham.

Evcil, A. N. 2009. Wheelchair accessibility to public buildings in Istanbul, Disability and Rehabilitation 4(2): 76-85. http://dx.doi.org/10.1080/17483100802543247

Francescato, G. 1991. Housing quality: technical and non-technical aspects, in Bezelga, A.; Brandon, P. (Eds.). Management, quality and economics in buildings. London: E \& FN Spon, 602-609.

Hashim, A. E.; Samikon, S. A.; Ismail, F.; Kamarudin, H.; Jalil, M. N. M.; Arrif, N. M. 2012. Access and accessibility audit in commercial complex: effectiveness in respect to people with disabilities (PWDs), Procedia - Social and Behavioral Sciences 50: 452461. http://dx.doi.org/10.1016/j.sbspro.2012.08.049 
Goldsmith, S. 1997. Designing for the disabled: the new paradigm. Oxford: Architectural Press.

Ho, D. C. W.; Leung, H. F.; Wong, S. K.; Cheung, A. K. C.; Lau, S. S. Y.; Wong, W. S.; Lung, D. P. Y.; Chau, K. W. 2004. Assessing the health and hygiene performance of apartment buildings, Facilities 22(3/4): 58-69. http://dx.doi.org/10.1108/02632770410527789

Ho, D. C. W.; Yau, Y.; Poon, S. W.; Liusman, E. 2012. Achieving sustainable urban renewal in Hong Kong: strategy for dilapidation assessment of high rises, Journal of Urban Planning and Development 138(2): 153-165. http://dx.doi.org/10.1061/(ASCE)UP.19435444.0000104

International Code Council. 2009. Accessible and usable buildings and facilities (ICC A117.1-2009). International Code Council, Illinois.

Iwarsson, S. 1999. The housing enabler: an objective tool for assessment assessing accessibility, The British Journal of Occupational Therapy 62(11): 491-497. http://dx.doi.org/10.1177/030802269906201104

Junnila, S.; Horvath, A.; Guggemos, A. 2006. Life-cycle assessment of office buildings in Europe and the United States, Journal of Infrastructure Systems 12(1): 10-17. http://dx.doi.org/10.1061/(ASCE)10760342(2006)12:1(10)

Kadir, S. A.; Jamaludin, M. 2012. Users' satisfaction and perception on accessibility of public building in Putrajaya: access audit study, Procedia - Social and Behavioural Sciences 50: 429-441. http://dx.doi. org/10.1016/j.sbspro.2012.08.047

Kane, G.; Heaney, G.; Ewart, K.; McAlister, B. 2002. Developing an accessibility appraisal model for the external environments of housing estates, Facilities 20(3/4): 104-112. http://dx.doi. org/10.1108/02632770210423830

Mace, R.; Hardie, G.; Plaice, J. 1991. Accessible environments: towards universal design, in Preiser, W. F. E.; Vischer, J. C.; While, E. T. (Eds.). Design intervention: toward a more humane architecture. New York: Van Nonstrand Reinhold, 156-187.

National Research Council Canada and Institute for Research in Construction. 2010. National building code of Canada, 2010. National Research Council Canada and Institute for Research in Construction, Ottawa.

Ormerod, M. 2005. Undertaking access audits and appraisals: an inclusive design approach, Journal of Building Appraisal 1(2): 140-153. http://dx.doi. org/10.1057/palgrave.jba.2940013

Peloquin, A. A. 1994. Barrier-free residential design. New York: McGraw-Hill.

Polatidis, H.; Haralambopoulos, D. A.; Brulnsma, F.; Vreeker, R.; Munda, G. 2009. Decision aid with the MCDA-RES software: a wind-hydro energy application for an island of the Aegean, Greece, Energy Sources B: Economics, Planning and Policy 4(4): 407-419.

Sawyer, A.; Bright, K. 2007. The access manual: auditing and managing inclusive built environments. Oxford: Blackwell Publishing.
Seo, S.; Aramaki, T.; Hwang, Y.; Hanaki, K. 2004. Fuzzy decision-making tool for environmental sustainable buildings, Journal of Construction Engineering and Management 130(3): 415-423. http://dx.doi. org/10.1061/(ASCE)0733-9364(2004)130:3(415)

So, A. T. P.; Wong, K. C. 2002. On the quantitative assessment of intelligent buildings, Facilities 20(5/6): 208216. http://dx.doi.org/10.1108/02632770210426693

Tam, C. M.; Tong, T. K. L.; Leung, A. W. T.; Chiu, G. W. C. 2002. Site layout planning using nonstructural fuzzy decision support system, Journal of Construction Engineering and Management 128(3): 220-231. http://dx.doi.org/10.1061/(ASCE)07339364(2002)128:3(220)

Tam, C. M.; Tong, T. K. L.; Chiu, G. W. C. 2006. Comparing non-structural fuzzy decision support system and analytical hierarchy process in decision-making for construction problems, European Journal of Operational Research 174(2): 1317-1324. http://dx.doi. org/10.1016/j.ejor.2005.03.013

Thapar, N.; Warner, G.; Drainoni, M.; Williams, S. R.; Ditchfield, H.; Wierbicky, J.; Nesathurai, S. 2004. A pilot study of functional access to public buildings facilities for persons with impairments, Disability and Rehabilitation 26(5): 280-289. http://dx.doi.org/10.10 80/09638280310001649543

The Center for Universal Design. 1997. The principles of universal design. The Center for Universal Design, College of Design, North Carolina State University, Raleigh.

United Nations. 2006. Convention on the rights of persons with disabilities. New York: United Nations.

Wood, S. 1999. Access for disabled people to school buildings: management and design guide. London: Stationery Office.

World Health Organization and the World Bank. 2011. World report on disability. Geneva: World Health Organization.

Wu, S.; Lee, A.; Tah, J. H. M.; Aouad, G. 2007. The use of a multi-attribute tool for evaluating accessibility in buildings: the AHP approach, Facilities 25(9/10): 375389. http://dx.doi.org/10.1108/02632770710772478

Yau, Y. 2012. Multicriteria decision making for homeowners' participation in building maintenance, Journal of Urban Planning and Development 138(2): 110-120. http://dx.doi.org/10.1061/(ASCE)UP.19435444.0000108

Yau, Y.; Chan, H. L. 2008. To rehabilitate or redevelop? A study of the decision criteria for urban regeneration projects, Journal of Place Management and Development 1(3): 272-291. http://dx.doi. org/10.1108/17538330810911262

Yau, Y.; Ho, D. C. W.; Chau, K.W. 2008. Determinants of the safety performance of private multi-storey residential buildings in Hong Kong, Social Indicators Research 89(3): 501-521. http://dx.doi.org/10.1007/ s11205-008-9246-3 